\title{
RECENZIJA
}

\section{VOJAŠKE DRUŽINE: DINAMIKA, PREDNOSTI IN IZZIVI}

Družinski odnosi so ena izmed najdragocenejših človekovih izkušenj tako znotraj kot zunaj vojske, zato lahko morebiten razdor ali nesoglasje v družini močno vpliva na posameznike in družbo. Podpora družini lahko vpliva tudi na poklicne kazalnike, kot so pridobivanje in zadrževanje kadra ter pripravljenost vojske. Pripadnost družine vojaški službi se lahko prenaša iz generacije v generacijo in vpliva tudi na javno podporo vojski kot instituciji. Tokratna tematska številka Sodobnih vojaških izzivov je v celoti posvečena medsebojnemu vplivu družine, vojske in širše družbe.

Ponuja nam informativni sociološki vpogled v tematiko »vojaških družin « v Sloveniji in tujini. Vsak prispevek obravnava svojevrstna in pomembna vprašanja, povezana $\mathrm{z}$ vojaškimi družinami ter družbo. Za napredek pri zagotavljanju podpore vojaškim družinam je pri raziskovanju dejavnikov tveganja in zaščite treba uporabiti socialno-ekološki model raziskovanja v kombinaciji z na implementaciji temelječim znanstvenim pristopom in osredotočenostjo na dejavnike v okolju. Vsi članki v tej številki poudarjajo celovitost in pomen naslavljanja posebnosti vojaških družin $\mathrm{v}$ politikah, ki se s tem ukvarjajo.

Na področju družinskih ved se premalo pozornosti namenja implementaciji rezultatov znanstvenih raziskav, za kar bi bilo treba preučiti tako sedanje kot pretekle politike ter njihov vpliv na družine na različnih socialno-ekoloških ravneh. Zgodovinski vidik družine in njenih odnosov z vojsko v Sloveniji in tujini je lahko dobra podlaga za obravnavo politik in smeri raziskovanja (Jelušič, Jelušič Južnič in Juvan, 2020). Raziskave o vojaških družinah v Slovenski vojski so razmeroma novo, a vedno pomembnejše področje, če upoštevamo spremembe, do katerih je prišlo v zadnjih treh desetletjih, sploh po tem, ko se je preoblikovala v prostovoljno in poklicno vojsko. Avtorji se podrobno ukvarjajo z organizacijskimi in političnimi spremembami v Sloveniji, ki so potekale hkrati z raziskovanjem vojaških družin doma in v tujini. 
Čeprav je pomen vojaških družin zdaj širše prepoznan, še vedno obstajajo ovire za uspešno uresničevanje podpornih programov. Hess (2020), Jakopič (2020) in Kasearu et al (2020) v svojih prispevkih navajajo več primerov podpornih programov, ki lahko vojaške družine okrepijo in povečajo njihovo pripravljenost. Za doseganje najboljših rezultatov se je tako treba usmeriti ne le v reševanje težav, temveč tudi v primarno preprečevanje dejavnikov tveganja in spodbujanje odpornosti družin, na primer s spodbujanjem kakovostnih medosebnih odnosov, za kar je nujna podpora na več ravneh delovanja, vključno s psihološko podporo, socialnim varstvom, pravnim svetovanjem in duhovno oskrbo.

Poleg kontekstualnih vidikov in preučevanja politik je temeljni del raziskovanja vojaških družin tudi opredelitev tveganja in zaščite na različnih socialno-ekoloških ravneh s pomočjo empiričnih raziskav. Vuga (2020) opisuje akcijski načrt aktualne raziskave, katere cilj je opredeliti dejavnike, ki na različnih socialno-ekoloških ravneh vplivajo na družine. Prihodnji programi in politike se lahko torej navezujejo na tiste dejavnike tveganja in zaščite, ki so najustreznejši za zdravje družin v slovenskem vojaškem okolju. Tak pristop, ki temelji na javnem zdravstvu, se v drugih državah uporablja za seznanjanje vojaških voditeljev s potrebami njihove vojske. Pri našem sodelovanju z vojsko ZDA smo s pomočjo modelov dejavnikov tveganja in zaščite opredelili posebne prilagodljive kazalnike za predvidevanje vedenjskega zdravja in zdravja družin, ki bi jih lahko uporabili tudi pri delovanju na ravni posameznika, družine, stroke in družbe. Širjenje modela socialno ekoloških raziskav, ki ga izvaja Vuga s sodelavci, bo koristno za Slovensko vojsko, njegovi rezultati pa bi lahko bili koristni tudi za druge vojaške organizacije. Rezultati, ki jih bo prinesla uporaba modela dejavnikov tveganja in zaščite iz projekta MilFam - Vojaške družine v praksi, je mogoče v prihodnje preizkusiti v nadaljnjih študijah in tako zagotoviti učinkovito izvajanje in spreminjanje vedenjskega zdravja. Projekt bo pomenil pomemben korak pri zagotavljanju podpore vojaškim družinam v Sloveniji.

$\mathrm{V}$ preostalih člankih se avtorji ukvarjajo še $\mathrm{z}$ drugimi pomembnimi vidiki vojaškosocioloških raziskav, pri čemer obravnavajo razlike med državami, izzive ob napotitvah in demografske spremembe, ki vplivajo na koncept »vojaških družin«. Kasearu et al. (2020) v prispevku primerjajo koncept vojaških družin v treh različnih državah. Ali se družine obravnavajo kot del vojske ali ne, kot to velja za nekatere druge poklice, je odvisno od tega, kako je v različnih državah vojaška služba opredeljena. V nekaterih okoljih velja poudarek na izvajanju politik le za pripadnike oboroženih sil, ne pa tudi za civilne družinske člane. Čeprav so podobne politike skupne mnogim poklicem, zagotovo obstajajo posebni razlogi, da v vojski te politike in programi veljajo tudi za civilne družinske člane, kar ne koristi le vojaškim družinam, temveč vpliva tudi na boljšo pripravljenost vojske. Kadar veljavne politike ob napotitvah ne veljajo tudi za partnerja in otroke, ki ostajajo doma, lahko to privede do psiholoških stisk, finančnih bremen in slabše družinske dinamike. V digitalni dobi so pripadniki na misijah pogosto dobro obveščeni o težavah doma in se zaradi pomanjkanja veljavnih politik, ki bi podpirale tudi člane vojaških družin v času napotitve, lahko počutijo nemočne. 
Poleg izzivov, ki jih povzroča ločeno življenje, se vojaške družine spoprijemajo tudi s svojevrstnimi izzivi, ko je v tujino napotena vsa družina. V takšnih razmerah je bistveno, da se z infrastrukturo in povezovanjem zagotovita formalna in neformalna podpora družinskim članom, kadar se poskušajo znajti v novem okolju. To vključuje materialno in čustveno podporo družinskim članom med prilagajanjem na življenje v tuji državi. Nastanitev, zdravstvena oskrba, izobraževanje, jezik in možnosti zaposlitve za družinske člane so nekatere izmed skrbi, s katerimi se družine spoprijemajo med bivanjem v tujini. Pri tem lahko podporo daje vojska s svojimi notranjimi viri, a je vse odvisno od velikosti vojaške infrastrukture v tujini. Kadar ni na voljo zadostne notranje podporne infrastrukture, se nekatere izmed teh pomanjkljivosti lahko zapolnijo s sporazumi z državami gostiteljicami.

Švab (prav tako tudi Jelušič et al. in Kasearu et al.) v zvezi s tem poudarja, da je to področje še bolj kompleksno, saj izzivi, s katerimi se spoprijemajo vojaške družine, niso odvisni le od vojaške infrastrukture in politike, temveč tudi od družinske strukture in dinamike. Jelušič in sod. opisujejo, kako se je značilna družina pripadnika vojske razvijala skozi čas. Švab predstavi dinamiko družinske strukture v Sloveniji in njeno prepletanje z organizacijskimi potrebami vojske. Struktura družine se je v zadnjih desetletjih bistveno spremenila, kar postavlja vojaške družine pred nove izzive. Spremenjene družinske strukture predstavljajo raznovrstne dejavnike tveganja in izpostavljajo področja, na katera je treba usmeriti podporne programe. Delitev dela in družinskih vlog se v Sloveniji in po svetu še naprej razvija. Vedno več je raziskav, ki utemeljujejo pomen spola in delitve dela v vojaškem okolju. Podpora za pripadnice z otroki se razlikuje od podpore za njihove moške kolege, zato so morda potrebni bolj ciljno usmerjeni podporni programi. Pri uresničevanju potreb različnih praks, povezanih z vojaškimi družinami, je pri raziskovanju in njihovem prenosu v prakso treba nameniti pozornost tako formalnim kot neformalnim podpornim mrežam.

V tej tematski številki so omenjeni posebni primeri programov, s katerimi se že zagotavlja podpora vojaškim družinam, vendar ni pomembno le, da se programi izvajajo, temveč tudi, da so to učinkoviti programi, katerih izvajanje izhaja iz potreb, prepoznanih v empiričnem raziskovanju. Tak primer je program PREP (angl. Preparation and Relationship Enhancement/Education Programme, program za pripravo in izboljšanje odnosov ter izobraževanje), s katerim več držav zagotavlja podporo pri odnosih med vojaškimi pari. Številne študije so pokazale, da se $\mathrm{s}$ programom stiske v odnosih sčasoma zmanjšajo.

Ta številka Sodobnih vojaških izzivov jasno kaže na to, kako zelo je družina za učinkovito strokovno delo pomembna. Ne glede na pomen vojaških družin te pogosto niso deležne dovolj različnih vrst podpore, na primer v obliki politik ali preprečevalnih ukrepov, ki temeljijo na resničnih potrebah družin. To ne vpliva le na strokovne kazalnike, kot so zadovoljstvo na delovnem mestu, zadrževanje kadra, izostanki z dela in zadovoljstvo z vodstvom, temveč družine izpostavlja stiskam in psihološkim težavam, kaže pa se lahko tudi v slabši delovni učinkovitosti. Ločitve ali razhodi in samsko življenje, torej družbena osamitev, so povezani tako s tveganji 
za pojav depresije in samomorilnih nagnjenj kot s slabo delovno učinkovitostjo. S podpornimi programi je zato treba naslavljati tako spremembe v družinski strukturi, ki so lahko še posebno stresne, kot negativne dejavnike stresa v družinah, na primer nesoglasja in nasilje v družini, kar prav tako vpliva na delovno učinkovitost. Tokratna tematska številka opozarja prav na to povezanost (med zadovoljstvom pripadnikov in njihovih družin ter uspešnim delovanjem vojaške organizacije, op. ur.) in bo lahko uporabna referenca za prihodnje raziskovalne študije in politike v korist vojske in vojaških družin. 